\title{
Contemporaneidade e Vida Privada. Olhares interdisciplinares sobre o Brasil
}

\author{
Marcos SILVA ${ }^{\bullet}$
}

\begin{abstract}
Resumo: Este artigo discute o livro Contrastes da intimidade contemporânea. O texto analisa suas concepções de periodização, territorialidade, sociabilidades e outras dimensões de método em História. Ele aponta conquistas e limites nesse diálogo entre Ciências Sociais e Conhecimento Histórico.
\end{abstract}

Palavras-chave: História da vida privada - Interdisciplinaridade - Brasil, século XX.

O livro Contrastes da intimidade contemporânea é o último e mais extenso volume da série "História da vida privada no Brasil", dirigida por Fernando Novais. A antropóloga Lilia Moritz Schwarcz coordenou esse tomo ${ }^{1}$.

A trajetória profissional de Schwarcz é marcada pelo diálogo com o conhecimento histórico, a partir de estudos sobre relações raciais e racismo no Brasil. Sua tese de livre-docência traçou um perfil de Pedro II, imperador brasileiro.

A importância da interdisciplinaridade para o conhecimento histórico foi salientada especialmente a partir da criação da revista erudita francesa Annales, em 1929. Suas ligações com a Antropologia se deram, nesse início, através da tradição durkheimiana, em especial, de Marcel Mauss. É possível identificar tópicos desse diálogo (materialidade da cultura e dimensão cultural do corpo) nos livros de Marc Bloch Os reis taumaturgos, Caracteres originais da história rural francesa e Apologia da História ou Ofício do historiador. O tempo

\footnotetext{
- Professor Titular - Departamento de História - FFLCH - Universidade de São Paulo - USP - 05508-900 - São Paulo - SP - Brasil. E-mail: marcossilva.usp@uol.com.br
} 
histórico aparece como o outro etnográfico em $O$ problema da descrença no século XVI, de Lucien Febvre, que salienta a importância do olfato para os homens da França quinhentista. Historiadores mais recentes ligados a essa tradição ampliaram tal diálogo².

A abrangência do conhecimento histórico, em termos de temas e explicações, foi lembrada por um dos historiadores da "Nova História", Paul Veyne, retomando discussões que vêm do século XIX e embasam a possibilidade infinita do debate interdisciplinar ${ }^{3}$. Um risco, nesse passo, é transferir para outras disciplinas tarefas técnicas e teóricas que são também da História, transformando interdisciplinaridade em parasitismo. Seria limitador dividir papéis entre historiadores e cientistas sociais através de critérios temáticos ou de periodizações. Tratase de pensar sobre sutis nuances (ênfase conceitual, peso e crítica da referenciação documental, reflexão sobre a temporalidade das experiências), compartilhadas entre as Ciências Humanas.

Lilia argumenta que, entre nós, “(...) poucos profissionais da área (História) vêm se dedicando, de forma prioritária, à análise da 'história imediata". Daí, justificar a opção por uma equipe interdisciplinar para o volume. Três dos ensaios que o compõem resultaram do trabalho das antropólogas. Um é obra de cientista política, junto com jornalista. Outro veio de uma demógrafa. Dois mereceram a abordagem de sociólogos. Por fim, três foram escritos por historiadores, um em colaboração com economista.

Alguns indícios sugerem que o argumento de Schwarcz sobre escassa atenção de historiadores brasileiros em relação à História do passado recente ou do presente não tem fundamento, observando-se que: 1) existe uma tradição clássica na Historiografia brasileira de abordar essas questões, representada por nomes como Euclides da Cunha, Sérgio Buarque de Holanda, Caio Prado Jr. e Gilberto Freyre; ; 2) também existe uma tradição de abordar tais questões entre os jovens pesquisadores arrolados num balanço de teses e dissertações dos principais programas brasileiros de pósgraduação em História. Nele, podem ser identificados temas 
como MST, sindicalismo na ditadura e depois, redemocratização e cultura brasileira recente ${ }^{5}$; 3 ) a História Oral se consolidou, no Brasil, como gênero de pesquisa, desde a segunda metade dos anos 70 do século $X X$, está disseminada em diferentes programas brasileiros de pesquisa e há uma instituição de referência nessa área, entre nós: o CPDOC/FGV (Rio de Janeiro).

Apesar dessa inadequação argumentativa, cabe ressaltar a excelência intelectual dos não-historiadores convidados. São pesquisadores prestigiados em suas áreas e ligados a horizontes de historicidade.

O recorte central de periodização anunciado por Lilia vai dos anos 40 aos 90 do século XX. Seu final diz respeito ao momento em que o livro foi escrito. O ponto de partida evoca Getúlio Vargas (CIC, p. 8) e ampliação do setor industrial. São marcos da política institucional e da economia, duvidosos em relação à vida privada.

Trata-se de uma dificuldade geral da série: em Cotidiano e vida privada na América Portuguesa, ausência de estado nacional e definição dessa América como portuguesa (viés administrativo: na vida social, a presença indígena e africana é muito forte, como demonstrado desde Freyre, com os antecedentes de Sylvio Romero ${ }^{6}$ ); em Império - A Corte e a modernidade nacional, existência de estado nacional monárquico e ação centralizadora da Corte; em República: Da Belle Époque à Era do rádio, existência de estado nacional republicano e ação centralizadora da Capital Federal.

A prioridade atribuída aos marcos da política institucional é válida, em termos de periodização, para a política institucional. Transferi-la para a vida privada anula especificidades desse campo. E perde de vista a flexibilidade das periodizações própria ao conhecimento histórico: cada modalidade de experiência remete a múltiplas articulações. É possível que essa escolha se deva à maior facilidade de contato com o leitor, já habituado a recortes clássicos. Trata-se de critério de mercado próprio a uma coleção voltada para público diversificado.

Os diversos ensaios que compõem Contrastes da intimidade contemporânea realizam diferentes recortes de 
periodização, de acordo com especificidades temáticas ou preferências interpretativas de seus autores.

Boris Fausto ("Imigração: cortes e continuidades") volta-se para o início do século XX. Essa concentração se articula ao grande peso dos movimentos populacionais, em escala internacional, naquele período. Como se concentra no período anterior aos anos 30 do século XX, Fausto não aborda o racismo brasileiro em relação a judeus e asiáticos, que se manifestou especialmente durante o Estado Novo (tempo de Nazismo e Segunda Guerra). Encerrando o ensaio, Boris cita a crescente importância das migrações internas para São Paulo e Sudeste, desde os anos 30 do século XX, e a presença recente de novos contingentes imigrantes, representados por asiáticos, latinoamericanos e africanos. Nada diz sobre a inversão internacional dos deslocamentos humanos, nas duas últimas décadas do mesmo século, com a saída de milhares de brasileiros para outros países - EUA, Japão, travestis na Europa. Não comenta as denúncias de trabalho escravo entre chineses, coreanos e latinoamericanos ilegais no Brasil, nem as diferentes máfias na São Paulo da passagem para o século XXI.

Ângela de Castro Gomes, no texto "A política brasileira em busca da modernidade: na fronteira entre o público e o privado", também atribui um peso decisivo às décadas iniciais do século XX (abre e fecha o ensaio falando de Rui Barbosa), mas desdobra essa atenção para Revolução de 1930, Estado Novo e Populismo, tratando concisamente da ditadura de 1964/1985 e da "redemocratização". Além de comentar o legalismo de Barbosa, em contraste com o caudilhismo de Pinheiro Machado, Gomes assinala a importância de Oliveira Vianna para a definição daquela modernidade ${ }^{7}$. Sobre o período mais recente, dá especial atenção a Juscelino Kubitschek. Ângela pensa esses tempos a partir da ação de Estado, lideranças e intelectuais, atribuindo menor peso às práticas das bases sociais, que figuram no ensaio como projetos daqueles outros sujeitos.

Os textos de Montes, Schwarcz, Berquó e Martins são exemplos de diálogos entre a segunda metade do século XX e períodos anteriores. 
Abordando o Catolicismo na tradição brasileira, Maria Lúcia Montes ("As figuras do sagrado: entre o público e o privado") aponta um processo de decadência da Igreja Católica, no plano internacional, a partir do século XIX, compensado, na passagem para o século XX, pela experiência da romanização ${ }^{8}$. Maria Lucia também salienta o teor "privatizante" da Igreja Católica Romana no Brasil, desde o início da república até meados do século XX, através da prioridade atribuída à prática espiritual, no âmbito da família e na ação do indivíduo. Caracteriza-a, ainda, por elitismo e ligação privilegiada com hierarquia do estado ou das classes dirigentes.

Um primeiro traço das tradições afro-brasileiras que Montes realça é a experiência de distorção nas relações com o poder colonial. Tais tradições, no plano religioso, estavam apoiadas no culto dos ancestrais, e a visão senhorial as tolerava como divertimento, ou as reprimia como feitiçaria. A partir de fins do século XIX, as elites nacionais passaram a desqualificálas em nome de modernidade, razão e ciência, perseguindo os fiéis do Candomblé, inclusive no plano policial, até os anos 30 do século XX. Algumas mudanças nesse panorama se fizeram sentir quando as tradições culturais africanas passaram a ser entendidas como parte da identidade nacional, pelos modernistas e seus sucessores. Nos anos 20 e 30, Maria Lúcia identifica o nascimento da Umbanda a partir de mesclas entre elementos de Candomblé, Espiritismo, Evolucionismo e Positivismo. Já o Candomblé, em sua vertente mais "clássica", manteve-se em alguns núcleos (Salvador e Rio de Janeiro) e cresceu em São Paulo a partir dos anos 60, num contexto de crise de valores e nascimento da contracultura.

Montes expõe como as tradições africanas sobreviveram sob a hegemonia do Catolicismo, vinculado ao estado metropolitano e acomodado ao etos da sociedade colonial. Esse Catolicismo é considerado barroco, marcado por magia e relação com os santos como intercessores. A festa era legitimação cívico-religiosa do poder, e a sedição vista como doença. O cortejo tornava visível a hierarquia social e a religião fazia a mediação público/privado. Maria Lúcia entende que o 
Catolicismo barroco sobreviveu até o século XIX, tendo por função soldar elites e povo, via festa. Com o fim do império e o começo da república, a festa se manteve como atributo popular, entendida na condição de folclore. A Igreja romanizada combateu o Catolicismo popular, defendendo valores burgueses (moderação, recato) e atacando as Folias de Reis. Nessa situação, as culturas afro-ameríndias puderam transformar-se e resistir.

Embora mais voltada para o período posterior aos anos 30 do século XX, Schwarcz ("Nem preto nem branco, muito pelo contrário: cor e raça na intimidade") destaca que a escravidão "legitimou a inferioridade e, enquanto durou, inibiu qualquer discussão sobre cidadania", bem como "o trabalho limitou-se exclusivamente aos escravos" (CIC, p. 185). A última afirmação é excessiva: mesmo no período colonial, determinadas tarefas foram reservadas ao trabalho assalariado - caso de atividades especializadas no engenho. A questão de legitimar a inferioridade é muito significativa, mas houve nuances da cidadania brasileira em construção, no século XIX, ou mesmo antes, que passaram pela presença escrava na cena pública ${ }^{9}$. A associação entre essas teorias racistas e a república no Brasil não deve fazer esquecer que argumentos similares se faziam presentes noutras partes do mundo à época, assumindo contornos específicos em cada historicidade nacional - EEUU, por exemplo.

Elza Berquó ("Arranjos familiares no Brasil: uma visão demográfica") trabalha informações obtidas nos recenseamentos. Embora mencione brevemente dados do século XIX e do início do século $X X$, sua atenção se volta prioritariamente para o período posterior a 1940. E é nesse universo temporal que Berquó aponta dimensões como: estado conjugal, média de pessoas por unidade familiar e mercado matrimonial.

"A vida privada nas áreas de expansão da sociedade brasileira", de José de Souza Martins, concentra seu debate na segunda metade do século XX, apelando para experiências de observação direta, os registros fotográficos e as narrativas 
verbais resultantes dessas práticas. Entende esse presente ou passado recente, todavia, como dotado de "muitos cenários remanescentes daqueles cenários iniciais da Conquista" (CIC, $\mathrm{p}$ 660), mencionando a "persistência da mentalidade arcaica no âmago mesmo de um processo que parece pedir o novo e a inovação" (CIC, p 682). Noutra passagem, Martins entende que a língua daquelas pessoas é "um português que se falava no período colonial, um português de literatura antiga" (CIC, p 712). O sociólogo trabalha com a noção de "descompasso de temporalidades" (CIC, p 685), pressupondo uma coerência ideal do tempo, ao invés de encarar os traços culturais apontados como elementos da coerência própria àquela temporalidade, sem discutir as condições contemporâneas que possibilitaram a manutenção daqueles vestígios. Nesse universo explicativo, Martins conclui: "Ali pude armar minha rede e depositar minhas coisas. Como no 'tempo dos bandeirantes'." (CIC, p 696). E também comenta:

Quando o trabalhador rural vitimado pela ameaça de expulsão, pela própria expulsão, pelo despejo e pelo próprio direito em que essas ações se fundam, dirige-se aos governantes, pensa logo no presidente da República, a quem imagina como um pai da pátria do século XVIII e de quem espera uma decisão pessoal, uma proteção pessoal." (CIC, p 719).

Essas homologias entre tempo presente ou recente e séculos anteriores requerem uma demonstração mais precisa, incluindo melhor caracterização do passado referido. Não fica demonstrado o que é "pai da pátria" no Absolutismo; nem como camponeses semelhantes a esses (?) se dirigiam por escrito aos reis do século XVIII. Falta explicar mais se as diferentes concepções de direito (popular e de estado) correspondem a diferentes temporalidades, ou a uma temporalidade internamente cindida. Embora o texto elabore uma brilhante crítica ao monopólio da Razão pelos detentores do capital e diferencie inteligentemente direito do dinheiro de direito do trabalho, a lógica popular é mais caracterizada como retroativa 
que a violência dos dominantes. O direito do trabalho não é só passado, expressa necessidades e lutas concretas dos pobres. A oposição entre luta pela terra e luta por diferentes concepções de direito (CIC, p 717) exige maior demonstração, embora Martins já advirta sobre aquelas experiências serem "aparentes sobrevivências de uma cultura vencida e do passado" (CIC, $\mathrm{p}$ 691).

Os ensaios "Para não dizer que não falei de samba: os enigmas da violência no Brasil", de Alba Zaluar, "Carro zero e pau-de-arara: o cotidiano da oposição de classe média ao regime militar", de Maria Hermínia Tavares de Almeida e Luís Weis, "Diluindo fronteiras: a televisão e as novelas no cotidiano", de Esther Hamburger, e "Capitalismo tardio e sociabilidade moderna", de João Manuel Cardoso de Mello e Fernando Novais, estão mais concentrados nos anos 40/90, ou em suas subdivisões.

Zaluar salienta como a violência cotidiana se destacou no universo dos debates que se seguiram ao fim da ditadura de 1964/1985. A abrangência desse uso foi integrada aos valores de jovens nele envolvidos (maioria de vítimas do sexo masculino, entre 15 e 39 anos), como conquista de glória e ruptura do anonimato. Crime e violência passaram a identificar, na Imprensa e noutros setores da opinião pública, o outro social. Alba destaca os riscos imediatistas de algumas avaliações: permanecer no plano local, quando o tráfico de drogas e armas é mundial; culpar os pobres pelo fenômeno, quando são suas principais vítimas e supor que a violência se concentra em alguma cidade do país, como o Rio de Janeiro. A autora finda abordando mais o universo carioca, embora faça referências a outras cidades brasileiras e de diferentes países.

O ensaio fala sobre os novos processos de difusão cultural e estilos de consumo que marcaram o mundo na passagem do século XX para o seguinte (já desde o segundo pós-guerra), junto com a crescente individualização, o predomínio de valores de mercado e a falta de compromisso com o espaço público. Dimensões dessa passagem para o século XXI são: a crescente importância da satisfação imediata (imagens especulares, 
consumo) e as mudanças no mercado de trabalho (informalização e precariedade). Zaluar sintetiza esse quadro na imagem de "um capitalismo que tenta fugir dos controles coletivos" (CIC, p. 256), associado à violência generalizada, cuja contrapartida seria um fortalecimento de instâncias associativas.

A expansão do crime se expressa na insegurança coletiva, no uso de armas e nas redes de segurança privada. Aumentou a produção de drogas ilegais, com destaque para a cocaína, desde meados dos anos 80, o que contribuiu para a queda de preço e a disseminação ampliada de uso. Seu tráfico passou a ser pago tanto em moedas (dólares e outras) quanto em outras mercadorias - "armas, veículos, toca-fitas, aparelhos eletrodomésticos" (CIC, p 258) -, configurando uma Economia em escala considerável.

Alba Zaluar lembra o fenômeno da mobilidade social descendente entre usuários (endividados, discriminados, desempregados), fazendo com que a fronteira entre eles e os traficantes seja permissiva. Ela aponta o predomínio de consumidores homens, jovens, desempregados, solteiros ou divorciados. Embora a produção e o comércio de drogas obedeçam a estilos diversificados, a autora salienta traços do negócio dedicado à cocaína, por seu predomínio: concentração na produção, cartelização no nível mais alto de comércio, descentralização nos níveis inferiores. O lucro está associado à ilegalidade.

O panorama de violência e criminalidade daí decorrentes foi apresentado em escala internacional, apontando ritmos diferenciados (na França e nos EEUU, desde os anos 60; no Brasil, a partir de fins da década seguinte), envolvendo disputas entre gangues. No caso dos EEUU, a estudiosa explicou essa crescente violência: "tanto por causa do orgulho associado à concepção guerreira da masculinidade quanto pelo acerto de contas no tráfico de drogas" (CIC, p 263).

Uma periodização da ditadura foi formalmente proposta por Almeida e Weis: 1) 1964/1968 - “(...) os dois primeiros presidentes militares concederam razoável liberdade de movimento às oposições" (CIC, p 328). Uma ditadura, por definição, é sempre 
limite de liberdade - agrediram presos políticos desde o $1^{\circ}$ de abril de 1964. O que é, então, essa "razoável liberdade"? É possível que Maria Hermínia e Luiz se tenham deixado seduzir pela personalidade de Castelo Branco, primeiro ditador: culto, poliglota, vivendo num apartamento de classe média. $O$ argumento de ditadores concedendo liberdade é memória instituída de ditaduras. Uma análise crítica poderia identificar doses de liberdade enquanto conquista de cidadãos: garantidas por artistas e públicos, em música popular e teatro; vitórias de quem fazia cada passeata; grupos de oposição surgindo ou sobrevivendo com seus próprios pés... 2) 1969/1974 - Os piores momentos da ditadura, com mais cenas explícitas de violência torturas, desaparições, mortes. Mas também foi o tempo do "milagre econômico": emprego, ascensão social e consumo (o "carro zero") para alguns, concentração de renda e baixos salários para a maioria. Nesse fogo cruzado, Maria Hermínia e Luiz mencionam o "desconforto bilioso e persistente [da classe média intelectualizada] com o cotidiano contaminado pela prepotência que descia do Planalto e se derramava pelas planícies" (CIC, p 333). A ditadura, então, derivava apenas do Palácio do Planalto, ocupado somente por militares? Escritórios e outros espaços civis de Bagé, Salvador, Londrina, Manaus, Campina Grande, Corumbá e mais lugares não destilavam venenos antidemocracia? Os autores introduzem o tema da "mudança dos padrões de conduta privada (...) Para a geração da classe média de esquerda (...)" (IDEM, Idem) - novos hábitos sexuais, consumo de drogas, etc.. "Classe média intelectualizada" vira sinônimo de "de esquerda". E as mudanças não ficaram restritas a ela - são de "geração". 3) 1975/1984 "rumo ao governo civil", quando o avesso de ditadura é anunciado como coisa de governo. Almeida e Weis fazem um paralelo com o primeiro momento ditatorial, na fluidez repressão/debate. Apontam, como importantes marcos desse momento: a nova valorização da democracia pela classe média, sua aproximação do MDB, o movimento pela Anistia, as eleições diretas para governador, as reunióes anuais da SBPC e o movimento pelas Diretas Já. Não mencionam: as greves desde o 
final dos anos 70 (inclusive, de professores e jornalistas), os movimentos contra a carestia (governo federal Geisel) e o desemprego (governo estadual Franco Montoro, São Paulo), nem a atuação de partidos menores e seu reingresso - ou primeiro ingresso, no caso dos novos - na legalidade. A valorização da democracia poderia ser confrontada com um argumento golpista: montar uma ditadura como forma de ser democrata.

Nessa periodização da etapa final do regime, consequências de uma adesão sem críticas à memória instituída se aprofundam: a ditadura continua restrita a sua face castrense, movimentos sociais e vozes partidárias com projetos diferentes do vitorioso somem. Derrotados não foram apenas os sujeitos da ditadura, alguns até muito valorizados na nova etapa - José Sarney, Delfim Neto etc. Observa-se a ausência de reflexão crítica sobre a periodização dominante, definida pelos gestores da ditadura, especialmente no anúncio de "distensão" e "abertura" por Geisel, Golbery e Figueiredo.

Esther aborda a televisão e as novelas como partes ativas de experiências dos anos '50 a '80. A escritora aponta as décadas de '70 e ' 80 como o auge do gênero no país. Depois, com o aparecimento de tv a cabo, vídeo-cassete e mais canais abertos, as telenovelas perderam audiência, embora continuem a ocupar importante papel na programação. Lembra que, a partir do surgimento no Brasil (anos '50), os canais privados de televisão contaram com financiamentos governamentais para aquisição de equipamentos. Essa relação se aprofundou com a ditadura, quando as telecomunicações passaram a ser consideradas dimensão estratégica da política. Na década de '70, a televisão consolidou-se como veículo de massa, em escala nacional. Hamburger avalia que a Rede Globo foi a principal beneficiária da situação, potencializando propaganda e marketing, usando o trabalho de "um grupo de criadores de esquerda vindos do cinema e do teatro" (CIC, p 455) - integrantes não identificados, com exceção de Lauro César Muniz, "Fiel a seus ideais de esquerda nacionalista..." (CIC, p 760, nota 40).

O ensaio considera esse crescimento da televisão articulado a outras transformações brasileiras do período, como HISTÓRIA, São Paulo, 28 (1): 2009 
maior urbanização, industrialização, proletarização do trabalho rural e mudanças na estrutura familiar. Ele avalia que as novelas contribuíram para o debate público de demandas presentes na sociedade, questão exemplificada com o tema da corrupção, na novela Vale tudo, da Rede Globo, em 1988, que Hamburger associa ao posterior impeachment contra Fernando Collor ${ }^{10}$.

O fim da ditadura e da censura, para essa autora, reforçou o peso dos critérios de mercado, que se tornaram os principais guias para as opções de programação, donde a vantagem de menor vínculo explícito com vieses partidários ou de outras naturezas institucionais. Valeria lembrar que tais instituições e o mercado não existem isoladamente, e que a aparente independência em relação a partidos políticos ou igrejas não significa desligamento absoluto: propriedade e vitória do Bem são realçadas e evocam argumentos de algumas daquelas entidades. Noutro trecho, Esther registra "negociação imaginária (...) que envolve autores, produtores, pesquisas de mercado, instituições como a censura, a Igreja e o público" (CIC, p 475), atestando nuances.

João Manuel Cardoso de Mello e Fernando Novais anunciam informalmente a periodização 1950/1979, que tem o mérito de evitar os marcos clássicos da política institucional: nem fim de Estado Novo (1945) nem fim da ditadura seguinte (1985). Mesclando momentos políticos diferentes, Mello e Novais identificam especificidades nesse Capitalismo, quae sera tamen: o sonho moderno abrange parte da ditadura.

Eles caracterizam 1964 como "mudança do 'modelo' econômico, social e político de desenvolvimento" (CIC, p 561 designação elegante para ditadura?), enfatizam alterações no plano do consumo, com vasto apelo a exemplos visuais (publicidade, em especial), e tendem a estabelecer inflexões absolutas sobre itens que continuam em uso, como ferros a carvão para passar roupa, vendidos em feiras livres nordestinas (IDEM, p 563/564). Atribuem ao período a introdução de tópicos já consumidos no país desde o início do século XX, caso do leite condensado (IDEM, p 565). Mas o texto se destaca pela caracterização de uma temporalidade a partir de vasto 
arrolamento de experiências - muitas delas com aparência de memória pessoal. É um procedimento agradavelmente surpreendente, em pesquisadores que se notabilizaram, antes, pela escrita num complexo nível estrutural ${ }^{11}$ - agora, a complexidade é outra.

Junto com esse mosaico periodizante, o livro também inclui diferentes espacialidades. Aquele anúncio de uma intenção nacional (CIC, p 8) efetiva-se mais plenamente nos ensaios de Berquó e Hamburger, que, sintomaticamente, apresentam diferentes mapas do país. Elza, além de mapas, inclui gráficos referentes a aspectos da população brasileira (idade, nupcialidade, separações e divórcios, índices por gênero).

Esther analisa, dentre outros tópicos, "A consolidação de uma indústria televisiva de proporções nacionais" (CIC, pp 444/459) e a generalização de usos e costumes das grandes cidades no território brasileiro. A autora salienta a forte presença da televisão em todo o país, áreas urbanas e rurais e diferentes grupos humanos. Hamburger entende a disseminação do veículo como capaz de eliminar "algumas barreiras sociais e geográficas" (CIC, pp 440), ao mesmo tempo em que reproduz desigualdades e discriminações, exemplificando com o excesso de brancos na programação, pouco condizente com os percentuais de negros e mulatos na população brasileira. Ela lembra que a televisão "capta, expressa e constantemente atualiza representações de uma comunidade nacional imaginária" (CIC, pp 441), pondo em contato grupos humanos diferenciados e distantes entre si, difunde informações, fortalece o consumo e constitui novo espaço público no âmbito da vida privada.

Faz falta assinalar: a paulatina perda de núcleos locais de produção televisiva (em música e teatro, por exemplo) - mais restritos, recentemente, à programação jornalística,- a consequente centralização dos núcleos geradores de programação, tendendo a apresentar algumas metrópoles brasileiras como modelos para o país, e a perda de espaços públicos de convívio. Caberia lembrar, também, um nordeste pasteurizado - há um sotaque nordestino cênico, falado apenas em telenovelas! -, essa característica, associada à consolidação 
de bordões e outras formas de expressão próprias a cada novela, podem assumir o papel de etnocídio, contribuindo para diminuir a pluralidade cultural. O cineasta Pier Paolo Pasolini comentou a desaparição de dialetos próprios aos diferentes bairros romanos, quando a televisão se implantou na Itália ${ }^{12}$. No Brasil, hegemonia da televisão e perda da Cultura popular misturam-se com escassez e frequente inacessibilidade (preços, horários de funcionamento) de instituições culturais eruditas - casas de concerto, museus, bibliotecas, etc.

Incursões regionais e locais de determinados ensaios são justificadas pelo campo temático explorado. É o caso de "A vida privada nas áreas de expansão da sociedade brasileira", de José de Souza Martins, mais voltado para Norte e Centro do país. Seria interessante discutir as regiões de onde vieram os grupos humanos para ali deslocados e evitar restringir algumas experiências apenas às áreas de expansão, como ocorre no trecho: "É nesses extremos que o irracional, como a destruição da natureza e o revigoramento do trabalho escravo, se torna racional para o capital" (CIC, pp 682/683). Cadê a destruição da natureza em escala nacional, e as denúncias de trabalho escravo no Paraná e noutros lugares do sul e do sudeste?

Boris Fausto e a dupla Maria Hermínia / Luís tendem a se concentrar mais em São Paulo.

Fausto enfatiza o meio urbano, traduzido como cidade de São Paulo. Um estudo monográfico sobre a imigração na metrópole paulistana é de grande interesse. Mas grande número de imigrantes se encaminhou para o meio rural, e também se instalou em diferentes áreas urbanas do país. O historiador demonstra zelo ao advertir sobre seu recorte (CIC, p 21), e o título do texto poderia explicitar esse percurso.

$O$ texto assinala o econômico como o maior fator para a emigração, associado aos preconceitos e às perseguições. Contrapartidas disso são: o desejo frequente de se retornar à terra natal como pessoa bem sucedida, os sentimentos de estranhar o novo país, rejeitar o espaço de onde se partiu e sentir falta de alguns de seus aspectos - clima, culinária, etc. A situação dos imigrantes, no Brasil, é relacionada a aspectos 
culturais e políticos de seus países de origem, e também da Economia mundial.

Almeida e Weis sugerem a abrangência nacional do debate sobre a "classe média intelectualizada", mas seu referencial empírico é quase só paulistano. É uma opção legítima, que exige ser explicitada para que não se confundam deduções feitas a partir da Rua Maria Antonia (sede da FFCL/USP) como práticas de todo o país.

O Rio de Janeiro é o principal cenário para as reflexões de Ângela de Castro Gomes, Alba Zaluar e Maria Lúcia Montes.

No caso de Gomes, a atenção que dedicou aos poderes instituídos (particularmente, o Executivo, mas também ao Legislativo) ajuda a entender o destaque atribuído ao primeiro Distrito Federal, que se desdobra, mais para o final do texto, em imagens também de Brasília.

Zaluar apresenta aspectos nacionais e mesmo internacionais de seu campo temático, mas explora em maior profundidade experiências no Rio de Janeiro, da rica sociabilidade nos morros (a menção ao samba, no belo título do ensaio, diz respeito a isso - antes da ascensão da violência nas décadas finais do século $\mathrm{XX}$ ) ao tráfico em escolas públicas.

Uma abordagem similar é desenvolvida por Montes. Ela comenta traços gerais de religiosidade no Brasil, traçando paralelos com experiências nos EEUU e na Europa. Mas estuda detidamente o convívio entre seus universos (Candomblé e Neopentecostais, principalmente) através das transformações sofridas pela favela de Acari, Rio de Janeiro, e por uma área nãoidentificada da periferia paulistana, no período de 1995/1996. Maria Lúcia evoca, em Acari, um mundo de pobreza e violência, onde a população é constituída por vítimas, marcado, na primeira data, por diferentes referências iconográficas nas ruas São Jorge, Ogum, Bíblia, símbolos do Terceiro Comando e do Comando Vermelho (grupos do tráfico de drogas) e Bob Marley presentes em pichações. Ela identifica nesse convívio entre imagens uma espécie de ecumenismo popular, até mesmo um ecumenismo social, exemplificado pelo funcionamento da Casa da Paz, instituição de assistência a crianças, separada do tráfico, 
embora convivendo com seus agentes no mesmo espaço social. Em sentido paralelo, a autora lembra exemplo de São Paulo, onde uma casa de santo, instalada na periferia, merecia respeito dos traficantes. Esse panorama sofreu mudanças rápidas em 1996. No Acari, o tráfico passou a potencializar a violência, com a banalização do terror, e uma mentalidade de ganhar dinheiro para consumir fora do bairro. Aqueles símbolos ecumênicos foram apagados. Também na periferia de São Paulo, pouco depois, o tráfico se tornou cada vez mais forte e, sintomaticamente, uma mãe-de-santo pequena, para evitar o envolvimento com drogas, incentivava um filho a estudar e a se tornar evangélico - imagens de respeitabilidade.

João Manuel Cardoso de Mello e Fernando Novais tendem a se concentrar mais no sudeste brasileiro, embora discutam uma problemática de caráter nacional - Capitalismo tardio e Modernidade perdida. A iconografia (muito expressiva, embora pouco explorada pelo texto) apresenta cenas de diferentes regiões do país e o ensaio estabelece diálogos entre Economia nacional e Mundialização.

Num volume tão marcado pela presença de cientistas sociais, muitos são os níveis de sociabilidade explorados. Um deles é o de classe.

Fausto registra fala do paulistano Diário Popular, em 1892, sobre os imigrantes como "classe média" enriquecida, associada à onda de carestia, ao mesmo tempo em que eram criticados os estrangeiros pobres, dos cortiços. $O$ tema requer mais esclarecimentos sobre os conceitos de classe média e pobreza na São Paulo daquele período, ainda tão próximo de escravidão.

No escrito de Maria Hermínia e Luís, o conceito de classe social é anunciado desde o título, "Carro zero e pau-de-arara: o cotidiano da oposição de classe média ao regime militar", associado a alguns recortes: melhoria no padrão de consumo (carro), ameaça daquele instrumento de tortura (pau de arara), fazer oposição ao regime. Reafirma-se o caráter militar da ditadura, tendência predominante em sua memória instituída e na boa consciência de civis. São relegadas: a importância de personalidades e instituições civis (Carlos Lacerda, Magalhães 
Pinto, Delfim Neto, Paulo Maluf, o jornal O estado de São Paulo, o IPES e o IBAD), as relações entre militares e estrutura de classes e as diferenças entre militares ${ }^{13}$.

Os autores deixaram “ (...) de fora (...) os políticos profissionais do Movimento Democrático Brasileiro (MDB), a Igreja [Católica] e ainda as oposições sindicais e populares de modo geral”, porque “(...) é escassa a literatura disponível no que diz respeito à interação vida pública-vida privada, que é o que mais interessa aqui" (CIC, p 326).

Existe, entretanto, farta bibliografia sobre os sujeitos mencionados e espaços como Associações de Amigos de Bairro, Sindicatos e Comunidades Eclesiais de Base; a Imprensa do período (com destaque para a alternativa) não deixou de refletir sobre faces daquela interação; MDB e Igreja Católica foram importantes referências para essa "classe média intelectualizada" ${ }^{14}$.

A abertura do ensaio assume um sabor de lembrança ficcional, alcançando um efeito de ideal-tipo: um grupo de amigos, profissionais com formação universitária, assiste, na televisão, à final da Copa do Mundo de 1970, mesmo achando que "aquela seleção (...) merecia ganhar todas as Copas em todos os tempos" (CIC, p 321). Torcer daquela forma era enfrentar, na intimidade, uma adesão de parte da classe ao regime. Uma fração dela encarnava seu ser (pois continuava a integrá-la) e seu outro num só corpo. A "classe média intelectualizada" não era adesista, militar, terrorista, sequer comunista: era o quê?

Almeida e Weis não analisam o incentivo e o aplauso de parcelas dessa classe ao golpe ${ }^{15}$ e falam genericamente que "setores da população comemoravam a queda do governo constitucional" (CIC, p 323), tema visível em fotografias reproduzidas sem discussão, entretanto. Enfatizam o apoio dos "estratos mais conservadores da sociedade" (IDEM, Idem) ao regime, sem os identificar.

O texto refere-se o tempo todo à classe média, embora esse conceito finde apenas vagamente identificado a profissões e escolaridades ("advocacia, jornalismo, publicidade, pesquisa de mercado, arquitetura" - CIC, pp 320/321), mais hábitos de 
consumo e comportamentos. Maria Hermínia e Luiz realçam mudanças nos costumes familiares e nas relações entre gêneros, considerando-as mais intensas na "classe média intelectualizada". Eles entendem que a participação política incluía o cotidiano familiar. Lembram como a ditadura identificava os novos costumes à estratégia da esquerda (o general Milton Tavares de Souza disse: "O movimento hippie foi criado em Moscou" - CIC, p 404). Como outras classes não merecem maior definição no ensaio, o quadro de relações a que a classe média pertence fica pouco claro.

Partindo dos padrões de consumo (alimentação, vestuário, higiene e limpeza), João Manuel Cardoso de Mello e Fernando Novais descrevem ocupações e modos de vida das classes sociais no Brasil dos anos 50 a 70 . Assinalam, por exemplo, a melhoria das condições de sobrevivência nas grandes cidades para os migrantes rurais (junto com os afro-descendentes, os mais explorados), associando o campo ao atraso. A mobilidade, para eles, manifesta-se não apenas em termos espaciais (cidade/campo, entre cidades), mas também no nível das classes e de suas subdivisões.

Mello e Novais caracterizam o empresariado nacional, destacando a posição central das multinacionais no poder econômico. Assinalam o peso dos baixos salários para a manutenção de serviços baratos, e modalidades de acumulação naquela economia. Nuançam ocupações de classe média, incluindo prestação de serviços para os economicamente privilegiados. Ao mesmo tempo, articulam esse processo aos "'trinta anos gloriosos' (1945-74)" do capitalismo mundial (CIC, p 646). O final do período é marcado pelo desemprego e pela queda em salários e padrões de consumo.

Martins sublinha a oposição entre propriedade privada e o mundo privado dos pobres, sendo o último marcado por privações. Assinala que:

(...) a suposição de que o capitalismo e sua expansão justificam tudo: o ilegal é legítimo e legitimado pela espécie de redenção histórica que a expansão capitalista parece representar na 
mentalidade dos 'pioneiros', dos técnicos, dos funcionários do Estado e dos próprios governantes" (CIC, pp 680/681).

Cabe lembrar o papel de intelectuais nessa legitimação. A situação de classe é mais definida pelo texto nos grupos dominantes, mas estes existem em relação às outras classes.

Os vínculos de gênero foram debatidos especialmente por Zaluar, Berquó, Hamburger, Mello/Novais e Martins. Evidenciam como a História das mulheres se encontra em expansão, ao contrário da História dos machos (doenças de trabalho, mortalidade mais cedo, identidade em crise), da qual figuram indícios em Berquó (nupcialidade, mortalidade, mulheres pobres chefiando famílias), Zaluar (o etos guerreiro masculino), Mello/Novais (diferentes ocupações profissionais) e Martins (solidão de garimpeiros, marido como "emprego da mulher" CIC, p 704).

Ao refletir sobre os jovens como principais vítimas e agentes da violência, Alba Zaluar salienta a crescente infantilização e feminização da pobreza no Brasil, como se observa nos altos percentuais de famílias pobres chefiadas por mulheres e na presença infanto-juvenil no mercado de trabalho.

Almeida e Weis falam numa "Cultura do protesto" própria à universidade, e realçam como essa cultura se mesclava, no cotidiano, com a política. Sobre os hábitos sexuais desses jovens, apontam visões masculinas (das relações simultâneas com várias parceiras à descoberta de que era melhor fazer amor com a namorada), quase não aparecendo os olhares femininos sobre essa questão, exceto num viés de insegurança.

Elza Berquó destaca as desvantagens femininas no mercado matrimonial, onde predomina a norma de marido mais velho, sublinhando o perfil demográfico desigual dos diferentes sexos.

Hamburger entende que as novelas ultrapassaram o público feminino inicial, divulgando, a partir dos anos '70, tramas predominantemente urbanas, que tomaram as classes médias como referencial e alvo e enfatizaram a ascensão social como saída para desigualdades. A imagem das personagens 
femininas sofreu mudanças: de esposa em casamento estável como modelo indiscutível (anos '50 e '60), chegou-se, nas décadas seguintes, ao reconhecimento da mulher separada, que pode reconstituir a vida amorosa e profissional, possui ocupação fora do lar, não prioriza a maternidade e valoriza a realização pessoal. Relações sexuais antes do casamento e adultério sem maior culpa fizeram parte dessas inovações comportamentais que as novelas reforçaram, correspondentes a mudanças na sociabilidade brasileira e mundial desde os anos '60. A presença masculina passou por menores alterações, exceto no que se refere à crescente visibilidade do corpo nu - principalmente, o tórax. Temas polêmicos, como reprodução assistida, casais gays de ambos os sexos e aborto, cresceram mais nesse contexto.

Esther nuança tais transformações, lembrando a aparição de tais temáticas nas novelas globais das 22:00 horas, que incluíam alguma dose de experimentação temática e questões socialmente mais ousadas. Em O grito (1975), havia uma criança com grave distúrbio (gritar a qualquer hora do dia ou da noite), hostilizada pelos moradores de seu prédio, além de um profissional de classe média, solitário e discreto que, na intimidade, se travestia. Em Sinal de alerta (1978), abordava-se a poluição ambiental e seus efeitos sobre a saúde. Sem se esquecer de Gabriela (1975, baseada no romance Gabriela, cravo e canela, de Jorge Amado), cheia de sensualidade, nem das doses de "realismo fantástico" em Saramandaia (1976). Alguns desses recursos narrativos foram retomados e ampliados pela Rede Manchete em outros horários e por outros canais.

João Manuel e Fernando trabalham os gêneros especialmente nos planos de produtos consumidos, estilos de vida, modalidades de trabalho e sexualidade - no último caso, num plano de generalização muito grande. Em relação ás mulheres, destacam as ocupações de empregadas domésticas e operárias, para as pobres, e a expectativa, no início do período, sobre apenas cuidar da família. Destacam a valorização da virgindade feminina, nos anos 50 e 60, e as transformações na moral a partir dessa última década. Enfatizam a crescente 
importância do amor romântico e liberdade na escolha do parceiro.

Martins tece comentários de grande interesse sobre as relações homem/mulher no interior da casa, mesmo no quarto do casal, indicando regras de intimidade, que remetem aos atos de fecundação e procriação. Ao falar sobre rituais funerários, ele lembra que o defunto "(...) pode contaminar, também, pessoas, especialmente as mulheres, pelo motivo simples de que é no corpo da mulher que se gera a vida, antagônica da morte." (CIC, p 703).

Cita ainda fala de uma prostituta ("A puta e o peão são da mesma classe"), interpretando a última expressão como“(...) a classe dos que não têm ninguém, ainda mais sujeitos ao cativeiro de quem os explora" (CIC, p 706).

Um desdobramento dessas considerações sobre gêneros são os debates referentes à família e aos grupos de idade.

A família e o lar de imigrantes são tratados por Boris como espaços de reforço das tradições étnicas - língua, religião e culinária. Eles estão imersos em alguma tensão entre gerações diante do contato das gerações mais jovens com os já brasileiros, em escolas e universidade, o que podia ameaçar a endogamia com o espectro da assimilação. Não fala sobre o surgimento de instituições escolares voltadas para jovens da classe média ou da elite imigrante e seus descendentes em São Paulo. Valeria a pena refletir, também, sobre trajetos ascensionais de alguns grupos como modalidades de assimilação, que ultrapassavam a vontade isolacionista de setores étnicos.

A moradia merece do historiador algumas caracterizações gerais, que abrangem das mudanças na arquitetura paulistana, via elite imigrante e suas residências (cheias de citações das culturas de origem), aos cortiços, passando por palacetes, casas médias e abrigos miseráveis, brevemente descritos. Em relação aos últimos, Fausto salienta a promiscuidade como avesso de vida privada, reiterando comentários da época estudada sobre intimidade exposta e devassada. Nesse caso, é possível pensar sobre o argumento de vida privada e de intimidade "ausentes" 
como uma instância de desqualificação daqueles pobres e de rebaixamento de seus salários.

Almeida e Weis comentam que o cotidiano da classe média de esquerda envolvia cuidados com o que se dizia na presença de empregadas domésticas, com a opinião de vizinhos sobre atividades na casa e com o que os filhos podiam comentar na escola. Foi lembrada, além da maior frequência na separação de casais, a ampliação da divisão de tarefas domésticas entre homens e mulheres. Algumas dessas mulheres sustentavam a família, enquanto os homens se dedicavam integralmente à militância, filhos não conviviam com os pais ou os conheciam por codinomes, parentes se encontravam raramente, e com extrema dificuldade. $\mathrm{O}$ apoio de pais e mães a militantes perseguidos ou presos assumiu grande importância, alguns deles até se tornaram militantes e essa situação se manifestou fortemente no Movimento pela Anistia.

O escrito de Berquó destaca a importância social da família desde o título ("Arranjos familiares no Brasil: uma visão demográfica"), falando sobre faixas etárias de matrimônio, uniões consensuais, separação e divórcio, dimensões e composições de grupos familiares.

Para Hamburger, nas telenovelas brasileiras, a partir dos anos '70, problemas políticos e sociais surgiram articulados ao universo das relações pessoais, como tramas amorosas e questões familiares.

O ensaio de Mello e Novais assinala as mudanças no lar (consumo de produtos industrializados, novos eletrodomésticos, higiene), afirmando mesmo, em relação à população rural dos anos 50, que "A vida social girava em torno da família conjugal, dos parentes, compadres e vizinhos" (CIC, p 576). Junto com a dinâmica de transformações daquele período, os dois autores descrevem diferenças na organização familiar e nos padrões de vida de acordo com as classes sociais, lembrando, por exemplo, a valorização do estudo entre os mais pobres. Outro traço que eles apontam é a crescente importância do futuro (e não mais da tradição) e da ascensão social nesse âmbito. Mencionam a tendência a menor número de filhos, via controle da natalidade. 
No texto de Martins, figura uma modalidade de contrato nupcial entre peões e garimpeiros, casados em suas terras de origem, com moças das novas terras: um contrato de prestação de serviços entre as partes, registrado em cartório. É uma experiência que ajuda a entender, também, peso e limites da religiosidade nesse meio.

Etnias e nacionalidades são outras dimensões de vínculos sociais trabalhados no livro.

Boris Fausto destaca a multiplicidade de origens dos imigrantes, e fala mais sobre judeus, italianos e japoneses, mencionando brevemente libaneses, quase nada comentando a respeito de portugueses, espanhóis e alemães. Em relação às sociedades de socorro mútuo, Fausto realça sua formação por nacionalidade ou região de origem e a importância dessas entidades para os imigrantes, num país carente de assistência social. O autor apresenta os bairros étnicos, em São Paulo, como refúgios para os imigrantes, num retorno a seu mundo de origem, onde conviviam com práticas religiosas, alimentação e outros tópicos de seu universo, exemplificando com judeus, no Bom Retiro, e italianos, no Brás.

Fausto registra, no caso dos que ascendiam socialmente, o afastamento dos bairros étnicos, como os judeus, que se mudaram para Higienópolis, e os italianos, instalados na Avenida Paulista. Essa questão convida a pensar sobre as articulações entre mundo de origem e novo mundo inclusivo, onde a ascensão social de alguns estava se dando. Os que continuaram pobres poderiam merecer maior atenção, ultrapassando o que certa documentação (relatórios governamentais, Imprensa) fala sobre promiscuidade e abordando, inclusive, a formação de redes assistenciais por etnia - asilos, orfanatos, etc. Falar prioritariamente de quem ascendeu no plano social pode reforçar outro tipo de preconceito - o de que todo judeu é rico, por exemplo.

A respeito das línguas dos imigrantes, Boris ressalta seu papel de resistência cultural e reforço da identidade, presente no círculo doméstico, e o aprendizado do padrão culto, no caso de italianos enriquecidos, já no Brasil, contraposto aos dialetos de 
origem. As tradições alimentares foram situadas numa função similar à das línguas, embora também figurem inusitadas combinações (entre judeus, cozinha sefaradi misturada a tópicos asquenaze e até aos mineiros torresmo e tutu de feijão!).

Montes, Schwarcz e Zaluar evocam diferentes aspectos culturais de etnias africanas no Brasil, com destaque para o universo religioso. Em Schwarcz, aparece o conceito de "raça social" para designar identificações derivadas de condições sócio-econômicas, caso de uma mulher, definida como branca pelo agente de recenseamento e que, caracterizando-se como negra ou parda, ouviu a pergunta/resposta: "Mas a senhora não é professora da USP?" (CIC, p 231).

Em Mello e Novais, afro-descendentes e migrantes rurais figuram na escala mais baixa da estrutura social.

Martins menciona os contatos entre posseiros e outros sujeitos das zonas de fronteira com os grupos indígenas, assinalando posturas preconceituosas, que chegam a questionar a humanidade dessa gente. Seu texto inclui belas imagens de índios, registrando adereços corporais destes que incorporam artefatos dos outros, contribuindo para superar a visão habitual de que esses povos só interessam quando se estuda a colônia. Faz falta saber mais sobre a visão dos indígenas a respeito dos que chegaram.

Preconceitos aparecem, também, noutros dos ensaios.

Fausto os registra em relação aos imigrantes, em autores paulistas como Guilherme de Almeida e Alfredo Ellis Jr., face da representação recíproca que recém-chegados e nacionais tinham uns dos outros. Seria interessante que o historiador também pensasse sobre a presença dos imigrantes europeus num país marcado por hierarquias raciais que privilegiavam os brancos e, ao menos até os anos 30 do século XX, apelavam para a ideologia do branqueamento como solução de problemas nacionais. Havia também preconceitos a favor desses brancos recém-vindos, "salvadores raciais" do Brasil, conhecedores de outras línguas e muito mais coisas, com a experiência de uma viagem transatlântica? Eles nutriam preconceitos em relação aos brasileiros, como sugerido por Boris no desprezo pela "suposta 
condição doentia, pela aversão ao trabalho" (CIC, p 26) dos já nacionais?

A arte de Lasar Segall parece responder negativamente à última questão, através das obras sobre homens e mulheres negros, expressões de fascínio visual, e de seu auto-retrato como homem de pele escura e grossos lábios, em encontro amoroso com mulher muito branca. Também os casais de homens italianos e mulheres afro-brasileiras junto com extensa prole, caricaturados por Voltolino ${ }^{16}$, podem sugerir uma articulação afirmativa dos imigrantes com a multiplicidade étnica do Brasil.

A situação de outro recíproco, que o historiador anunciara no início de seu percurso, incita o leitor a pensar também sobre o nacional como processo em permanente construção. Nele, afloram novos espaços culturais, que resultam do contato entre tantas etnias e grupos regionais, na cidade de São Paulo e no resto do país: gaúchos que tomam chimarrão no calor do Mato Grosso, nipo-brasileiros que desfilam em escolas de samba paulistanas, nordestinos que cozinham em cantinas italianas e restaurantes chineses de São Paulo, afro-descendentes que lutam sumô ou judô, norte-americanos que praticam capoeira em New York e mestiços brasileiros diversos que escrevem hai-kais ou transformam catarinenses Oktoberfeste em carnavais afrogermânicos podem ser exemplos desses diálogos infinitos entre experiências sociais, outros Brasis que os grupos de migrantes internos, imigrantes e emigrantes possibilitaram e continuam a possibilitar.

Maria Lúcia entende que a Igreja Universal do Reino de Deus explora um filão das religiosidades populares (teologia da prosperidade, combate ao demônio), reapropriando-se, de forma invertida e até preconceituosa, de tradições afro-brasileiras. A autora caracteriza a ênfase na prosperidade como um dom divino, luta contra o Maligno - tudo que não for pentecostal - e apelo ao exorcismo. As tradições africanas são consideradas faces desse Maligno. Observa-se uma apropriação pentecostal do afro-brasileiro, sob o signo do $\mathrm{Mal}$, chegando a uma espécie de Ecumenismo popular negativo, imagem fortemente distorcida de Candomblé e Umbanda. 
A demonização das religiões afro-brasileiras é interpretada por Montes como etnocídio, destruição de um patrimônio cultural, levando-as a grandes dificuldades de reprodução e tendência a retornar ao privado. Maria Lúcia critica o individualismo possessivo dessas posturas excludentes, pois as escolhas religiosas fazem parte de práticas sociais, no universo das comunidades de sentido, indicando a ameaça representada pelo Deus exclusivista: escolha a partir de pressão da comunidade ou de busca de comunidade.

Lilia Schwarcz introduz, na abertura de "Nem preto nem branco, muito pelo contrário: Cor e raça na intimidade", o tema do tornar-se branco, usando conto infantil brasileiro, de Chrysanthème (pseudônimo de Cecília Bandeira de Mello Rebelo de Vasconcelos), publicado em 1912: uma princesa nascera negra devido à má formulação de pedido que a branca rainha, sua mãe e até então sem filhos, fizera à rainha das fadas: "Oh! Como eu gostaria de ter uma filha, mesmo que fosse escura como a noite que reina lá fora.". No final da narrativa, Negrina, aquela personagem, se transforma em alva e feliz esposa do Príncipe Diamante - a felicidade é incolor e preciosa...

Esse episódio literário foi situado por Lilia nos quadros do projeto racista de branqueamento da população brasileira, disseminado na passagem para o século $\mathrm{XX}$, de acordo com a qual, "quanto mais branco melhor" (CIC, p 176), malgrado alguns argumentos contrários à miscigenação, vista como degenerescência. Importantes nomes do ensaísmo brasileiro aparecem entre esses ideólogos: Sylvio Romero, Euclides da Cunha, Roquette Pinto e Nina Rodrigues. O branqueamento é interpretado como vontade de ver desaparecerem os índios e negros da população nacional, conforme projeção de Roquette Pinto para o ano 2012.

A autora não mencionou alguns pioneiros críticos desses escritores e do racismo no mesmo período, como: o médico e educador Manoel Bomfim, que responsabilizou o parasitismo colonial (exploração ibérica) pela miséria na América Latina, e o romancista Lima Barreto, que expôs a condição trágica, a pobreza e a luta pela dignidade humana entre negros e mulatos. 
Também não foram realçadas conquistas interpretativas de Sylvio e Euclides, capazes de ultrapassar o paradigma racial, através de interesse empírico de registros da cultura popular (Romero) ou de sopro épico e grandeza estilística (Cunha) ${ }^{17}$.

No debate de Zaluar, fica evidente a capacidade de repressão legal ao tráfico e a outras modalidades de crime contra os infratores pobres, enquanto os ricos que dominam essas atividades se protegem, inclusive via corrupção da Justiça.

Segundo Hamburger, a comunidade imaginária virtual, elaborada nas telenovelas, assume características peculiares: mais branca e mais rica que a maior parte da sociedade brasileira, e dotada de possibilidades de ascensão social bem mais intensas que as observadas no país. Esther interpreta essa dimensão como maior acesso da população pobre a alguns dos aspectos da vida dos ricos. Vale enfatizar que existem estruturas narrativas do folhetim sustentando aquela comunidade: vitória do Bem sobre o Mal e solução justa de conflitos. O imaginário serve também para legitimar as diferenças sociais existentes, através de perfis idealizados dos grupos sociais, que sempre aparentam desfrutar de um consumo superior ao que se observa empiricamente naquelas classes: os pobres possuem casas e aparência física de classe média, a classe média tem experiências de ricos, o sofrer dos ricos é destacado.

As conclusões da escritora retomam esse problema do reforço conservador. Ela tanto destaca a capacidade interativa das novelas, tratando-as como precursoras dos "reality shows", quanto lembra o papel discriminatório que os programas sensacionalistas "populares" desempenham nos canais abertos, ao associarem a pobreza à violência e à barbárie: a comunidade imaginária reafirma divisões e preconceitos.

A vontade de divulgação que marca a série "História da vida privada no Brasil", e lhe garantiu grande sucesso editorial, tem como consequência um debate historiográfico contido, que facilita a leitura para quem não é profissional de História, mas produz alguns silêncios perturbadores. É o caso dos estudos sobre padrões de vida na população paulistana e do peso de 
não-imigrantes nesse universo, tão pertinentes ao ensaio de Boris Fausto, e que não mereceram sua atenção. $O$ escrito de Gomes deixa de discutir, também, os estudos sobre a memória de 1930, que se tornaram referência importante para o tema até para ser contestada, se for o caso ${ }^{18}$.

Num volume marcado pela diversidade de assuntos e análises, a pluralidade de acervos documentais é um traço permanente. Quase sempre, são bem referenciados, com exceção dos arquivos particulares. Uma rala temporalidade se manifesta na reprodução, por Fausto, de belas fotografias sobre cerimônias judias, desprovidas de datação, problema que igualmente se manifesta em relação a grupos de japoneses, libaneses, espanhóis, árabes, sírios e coreanos. Dificuldades no que se refere ao acesso e à preservação de fontes também não foram expostas, como é o caso dos materiais sobre a televisão: perda de acervos (incêndios, falências, descasos de emissoras) e barreiras impostas pelos arquivos privados dos diferentes canais (regras draconianas para consulta, cobrança de valores altos quando se autoriza esse contato).

Imagens e estatísticas são largamente utilizadas no livro, dando-lhe aspecto de magazine, o que não é, necessariamente, defeito. Materiais visuais e gráficos, todavia, são pouco incorporados às análises, com exceção de Montes, Zaluar, Berquó e Martins, atestando que a cultura visual é mais debatida pelos cientistas sociais, embora Mello e Novais reúnam bons exemplos de publicidade e Fausto reproduza belas fotos ${ }^{19}$.

As relações dos autores com os documentos históricos, em alguns momentos, não deram conta de superar o poder de autoridade das fontes através do apelo à crítica. Maria Hermínia e Luiz, por exemplo, citam o economista Roberto Campos, que foi ministro do Planejamento durante a ditadura de 1964/1985: " $E$ sumamente melancólico - porém não irrealista - admitir-se que, no albor dos anos 60, este grande país não tinha senão duas miseráveis opçóes: 'anos de chumbo' ou 'rios de sangue'" (texto de 1998 - CIC, p 352).

Como o parágrafo continua com um registro sobre a concepção utilitária de democracia pela esquerda, o leitor pode 
ser levado a identificar Campos como um democrata melhor. Faltou refletir sobre a função autolegimadora daquela fala, que repôs argumentos dos golpistas. Roberto não quis ver os rios de sangue a jorrar nos anos de chumbo: quer literalmente (torturas, assassinatos), quer em desdobramentos mais "sutis" - arrocho salarial, maiores desigualdades sociais, perdas de espaço público.

Hamburger assimila argumentos das redes de televisão sobre atendimento a desejos do público, sem maior ênfase na palavra final, que cabe às empresas: "A vivência cotidiana das novelas diárias por mais de trinta anos propiciou a participação indireta dos telespectadores e prenunciou os programas interativos e reality shows" - CIC, p 486.

As tradições da escrita historiográfica no Brasil se distribuem desde a Alta Literatura (Euclides da Cunha, Sérgio Buarque de Hollanda, Gilberto Freyre) até à escrita monográfica (demonstrativa, mais habitual no meio acadêmico) e passam pelos estilos jornalístico e didático, comuns nos meios de divulgação.

A série "História da vida privada no Brasil" situa-se entre a escrita monográfica, dirigida para outros profissionais, e o texto de divulgação em bom nível, próximo do jornalismo. Tal característica se mistura a um memorialismo (talvez saudosismo, manifesto em Fausto, Almeida/Weis e Mello/Novais) difuso, comum nos estudos sobre passado recente e presente, e a riscos de impressionismo. Rituais judaicos são descritos com base na vivência do próprio Fausto e em narrações de outras pessoas, mas os depoimentos não tiveram critérios de escolha dos narradores, data de registro nem condições de tratamento gravação, transcrição, edição - apontados.

Os textos de Montes, Zaluar e Martins destacam-se pela habilidade narrativa. Maria Lúcia fala sobre o agravamento da intolerância religiosa no Brasil de forma comovente e até assustadora. Alba apela para recursos semelhantes na caracterização da violência, limiar do horror. E José de Souza é responsável por um dos momentos mais bonitos do livro, quando comenta a expressão "mulher que não presta", associando-a a 
um ritual de dom e contra-dom (ela não presta para fornecer o sangue do hímen, em retribuição ao sêmen que lhe é entregue pelo macho, na cópula - CIC, p 699).

As importantes conquistas interpretativas trazidas por Contrastes da intimidade contemporânea convidam a refletir sobre desdobramentos possíveis de suas teses.

Destaca-se a percepção de que nem tudo é vida privada, donde a necessidade de debater esses temas junto com a vida pública. Se Richard Sennet falou em "declínio do homem público" ${ }^{20}$, é possível pensar também num declínio do homem privado: sua História floresce na mesma época em que existem os reality shows, quando tudo é filmado no dia-a-dia e se expande uma cultura dedicada ao voyeurismo. $\mathrm{E}$ a ideologia neoliberal elegeu o privado como espaço privilegiado - que fazer para ir além dela?

Também cabe enfatizar a reflexão conceitual de Martins, que estabelece diferenças entre intimidade e vida privada, ação coletiva e vida pública. Isso ajuda a entender que a vida privada não é de sempre, que ela possui uma historicidade.

Alba Zaluar desenvolve brilhante análise sobre a sociabilidade do samba. Falta um debate similar, no livro, em relação ao futebol, atividade que incluiu, no período abordado, a definição de estilos e culturas, o nascimento de craques e torcidas, a conquista de Copas do Mundo... A Copa de 1970 desempenha uma função estratégica no texto de Almeida e Weis, mas o esporte e sua cultura ficaram de escanteio.

Também as fronteiras da modernidade artística (Brasília, Poesia Concretista, Bossa Nova, Cinema Novo) foram, quando muito, mencionadas, ou sequer registradas.

Outra peculiaridade desse volume é a inevitável discussão política sobre o que dá e o que não dá para debater em relação a temas e personagens do presente e do passado recente. Ela deriva de questões como sigilo de informações e acesso a acervos documentais, que exigem redobradas astúcias de interpretação. Se toda História é uma escrita em aberto, a História contemporânea ainda o é mais, pela difícil chegada a certos documentos, junto com o excesso de outras fontes. 
É surpreendente, no livro, a ausência da História Oral, tão adequada à temporalidade abordada. A oralidade figura, em Contrastes da intimidade contemporânea, com traços frequentemente impressionistas (caso dos depoimentos usados por Fausto), indício da insuficiente interdisciplinaridade ali praticada.

A História do cotidiano e da vida privada detém-se prioritariamente em experiências da continuidade, em fazeres pouco visíveis. Faz falta, nesse livro, evocar mais a História do argumento da revolução (a vida privada não se compõe somente de vitoriosos, como bem debatido por Zaluar e Martins): muita gente viveu e morreu por e para ela, no período que o volume aborda. Se livros de História não tratarem do assunto, quem o fará? A carência de maior debate sobre esse problema se manifesta no texto de Almeida e Weis, que o aponta brevemente: a classe média de esquerda agia em nome de revolução, termo apropriado por seus inimigos, que assim designaram a ditadura de 1964. As revoluções foram derrotadas, e os historiadores precisam discuti-las, mais que lhes dar adeus - essa última atitude apenas os transformaria em ideólogos da pós-revolução. Como ensinou Nietzsche, mais que anunciar a morte de Deus, é preciso pensar sobre a dimensão descomunal desse evento ${ }^{21}$. E a revolução foi, explicitamente, invenção humana.

Por último, é importante lembrar que nem só de contemporaneidade vive a História. Garantir que o passado recente e o imediato sejam entendidos como História não se confunde com perda das múltiplas experiências de temporalidade. Contra o risco de se estabilizar o conhecimento das sociedades humanas num puro passado, é preciso evitar o presente contínuo e compreender os diferentes fazeres sociais.

Integrando uma série panorâmica sobre a História do Brasil, o livro Contrastes da intimidade contemporânea supera esse perigo presentista, que pode ameaçar, todavia, leitores menos cautelosos. 
SILVA, Marcos. Contemporary Times and Private Lives. An Interdisciplinary look into Brazil. História, v.28, n.1, p.511-546, 2009.

\begin{abstract}
This article discusses the book Contrasts of Contemporary Intimacy. The text analyzes its divisions into periods, territorial criteria, conceptions of sociability, and other features of Historical methods. It points out conquests and limits in this dialogue between Social Sciences and Historical Knowledge.
\end{abstract}

Keywords: History of private lives; Interdisciplinary studies; $20^{\text {th }}$ century Brazil.

\title{
NOTAS
}

1 SCHWARCZ, Lilia Moritz (Org.). Contrastes da intimidade contemporânea. São Paulo: Cia. das Letras, 1998 (História da vida privada no Brasil - 4).

${ }^{2}$ MAUSS, Marcel. Sociologia e Antropologia. Tradução de Lamberto Puccinelli. São Paulo: EPU/EDUSP, 1974.

BLOCH, Marc. Les caractères originaux de l'histoire rurale française. Paris : Armand Colin, 1968.

IDEM. Os reis taumaturgos: o caráter sobrenatural do poder régio França e Inglaterra. Tradução de Júlia Mainardi. São Paulo: Cia. das Letras, 1993

IDEM. Introdução à História (Apologie pour l'Histoire ou Métier d'Historien). Edição revista, aumentada e criticada por Etienne Bloch. Tradução de Maria Manuel, Rui Grácio e Vítor Romaneiro. Mira Sintra: Publicações Europa-América, 1997.

FEBVRE, Lucien. Problema da descrença no século XVI: A religião de Rabelais. Lisboa: Início, 1970.

LE GOFF, Jacques (org.). A Nova História. Tradução de Ana Maria Bessa. São Paulo: Martins Fontes, 1983. Ver em especial o texto "A Antropologia histórica", de André Burguière, pp 125/152.

${ }^{3}$ VEYNE, Paul. Como se escreve a História. Tradução de Antonio José da Silva Moreira. Lisboa: Edições 70, 1987 (Lugar da História - 20). 
MiCHELET, Jules. O povo. Tradução de G. C. C. Souza. São Paulo: Martins Fontes, 1988.

MARX, Karl. O capital. Tradução de Regis Barbosa et al. São Paulo: Nova Cultural, 1988.

ENGELS, Friedrich. Situação da classe trabalhadora em Inglaterra. Tradução de Anália Torres. Porto: Afrontamento, 1975.

WEBER, Max. Ensaios de sociologia. Tradução de Fernando Henrique Cardoso. Rio de Janeiro : Zahar, 1982.

DURKHEIM, Émile. Regras do método sociológico. São Paulo: Nacional, 1971.

${ }^{4}$ CUNHA, Euclides da. Os Sertões. Edição crítica por Walnice Nogueira Galvão. São Paulo: Ática, 2000. 1ª ed.: 1902.

BUARQUE DE HOLLANDA, Sérgio. Raízes do Brasil. 26ª ed.. São Paulo: Cia. das Letras, 1995 (1 ${ }^{a}$ ed.: 1938).

PRADO JR., Caio. A revolução brasileira. $2^{\mathrm{a}}$ ed. São Paulo: Brasiliense, 1966.

FREYRE, Gilberto. Ordem \& progresso. Rio de Janeiro: José Olympio, 1957.

${ }^{5}$ CAPELATTO, Maria Helena (Coord.). Produção histórica no Brasil (1985/1994). São Paulo: Xamã, 1995, 3 volumes.

${ }^{6}$ FREYRE, Gilberto. Casa grande \& senzala. 19a ed.. Rio de Janeiro: José Olympio, $1978 \quad\left(1^{\text {a }}\right.$ ed.: 1933).

ROMERO, Sylvio. Contos populares do Brasil. Edição anotada por Luís da Câmara Cascudo. Rio de Janeiro: José Olympio, 1954 (Documentos brasileiros - 75B). $1^{\text {a }}$ ed.: 1883.

${ }^{7}$ Caio Prado Jr., no prefácio à primeira edição de Evolução política do Brasil, destacou a importância de Oliveira Vianna, sem renunciar a diferenças interpretativas em relação a suas teses.

PRADO JR., Caio. "Evolução política do Brasil", in: Evolução política do Brasil e outros estudos. $4^{a}$ ed. São Paulo: Brasiliense, 1963, pp 5/94, trecho citado em nota da p 7 (1 $1^{\text {a }}$ ed.: 1933).

${ }^{8}$ Tal perspectiva poderia ser confrontada com:

MAYER, Arno. Força da tradição. A persistência do Antigo Regime 1848/1914. Tradução de Denise Bottmann. São Paulo: Cia. das Letras, 1987.

${ }^{9}$ ANTONIL, André João (João Antonio Andreoni). Cultura e opulência do Brasil. Introdução e vocabulário de Alice Cannabrava. São Paulo: Nacional, 1967 (1 $1^{\mathrm{a}}$ ed.: 1711). 
BARREIRO, José Carlos. Imaginário e viajantes no Brasil do século XIX Cultura e cotidiano, tradição e resistência. São Paulo: Editora UNESP, 2002.

${ }^{10}$ Ao menos um comentarista identificou a novela global Que rei sou eu? (1989) como divulgação ampliada (nacional e mítica) daquele candidato, peça informal de sua campanha presidencial:

BETTI, Paulo. "Comentário - Na marca do pênalti", in: NOVAES, Adauto (Org.). Rede imaginária: televisão e democracia. São Paulo: Secretaria Municipal de Cultura/Cia. das Letras, 1991, pp 203/204. OBS.: Aborda o texto "O dia seguinte", de Sérgio Micelli (pp 196/202).

${ }^{11}$ NOVAIS, Fernando A. Portugal e Brasil na crise do antigo sistema colonial. São Paulo: Hucitec, 1989 (Estudos históricos - 1) (1 $1^{\mathrm{a}}$ ed.: 1978).

MELLO, João Manuel Cardoso de. O Capitalismo tardio: contribuição à revisão crítica da formação e do desenvolvimento da Economia brasileira. São Paulo: Brasiliense, 1990 (1 $1^{a}$ ed.: 1984).

${ }^{12}$ PASOLINI, Píer Paolo. Écrits corsaires. Tradução para o francês de Philippe Guilhon. Paris: Flammarion, 1976.

${ }^{13}$ Os dois últimos temas figuram em livros de Werneck Sodré dos anos '60, que uma parte daquela classe média leu:

WERNECK SODRÉ, Nelson. História militar do Brasil. Rio de Janeiro: Civilização Brasileira, 1965.

IDEM. Memórias de um soldado. Rio de Janeiro: Civilização Brasileira, 1967.

${ }^{14}$ Dois expressivos exemplos sobre movimentos sociais:

ARNS, Paulo Evaristo, et al. São Paulo - Crescimento e pobreza. São Paulo: Loyola, 1976.

SADER, Eder. Quando novos personagens entraram em cena. Rio de Janeiro: Paz e Terra, 1988.

A respeito de Imprensa alternativa:

KUCINSKI, Bernardo. Jornalistas e revolucionários - No tempo da imprensa alternativa. São Paulo: Scritta, 1991.

${ }_{15}$ O Correio da Manhã, por exemplo, publicou o editorial "Basta!", contra Goulart, no dia 31 de março de 1964.

${ }^{16}$ BELUZZO, Ana Maria. Voltolino e as raízes do Modernismo. São Paulo: Marco Zero/CNpq, 1992 (Onde está a república?).

${ }^{17}$ BOMFIM, Manoel. América Latina - Males de origem. Rio de Janeiro: Topbooks, 1998. $1^{\text {a }}$ ed.: 1905. 
LIMA BARRETO, Afonso Henriques de. Triste fim de Policarpo Quaresma. 15 ${ }^{a}$ ed.. São Paulo: Brasiliense, 1976 (Obras Completas - II). $1^{\text {a }}$ ed.: 1915.

ROMERO, Sylvio. Contos populares do Brasil. Edição anotada por Luís da Câmara Cascudo. Rio de Janeiro: José Olympio, 1954 (Documentos brasileiros - 75B). $1^{\text {a }}$ ed.: 1883.

18 DECCA, Maria Auxiliadora. A vida fora das fábricas: Cotidiano operário em São Paulo (1920/1934). Rio de Janeiro: Paz e Terra, 1987.

SILVA, Zélia Lopes da. A domesticação dos trabalhadores nos anos 30. São Paulo: Marco Zero/CNpq, 1990 (Onde está a república?).

SANTOS, Carlos José Ferreira dos. Nem tudo era italiano - São Paulo e pobreza (1890/1915). São Paulo: Annablume/FAPESP, 1998.

DECCA, Edgar de. O silêncio dos vencidos. São Paulo: Brasiliense, 1981. VESENTINI, Carlos Alberto. Teia do fato: uma proposta de estudo sobre a memória histórica. São Paulo: Hucitec/USP, 1997.

${ }^{19}$ Esse tema foi discutido, em linhas gerais (sem se referir ao livro CIC), no artigo:

MENESES, Ulpiano Toledo Bezerra de. "Fontes visuais, cultura visual, história visual. Balanço provisório". Revista Brasileira de História. São Paulo: ANPUH, 23 (45): 11/36, 2003.

${ }^{20}$ SENNET, Richard. O declínio do homem público: as tiranias da intimidade. Tradução de Lygia Araújo Watanabe. São Paulo: Companhia das Letras, 1988.

${ }^{21}$ NIETZSCHE, Friedrich. Gaia ciência. Tradução de Alfredo Margarido. Lisboa: Guimarães, 1977.

Numa edição brasileira de fragmento dessa obra, figuram os trechos:

"Como conseguimos beber inteiramente o mar? (...) Não anoitece eternamente?"

IDEM. Idem (fragmento), apud: IDEM. Genealogia da moral. Tradução de Paulo César Souza. São Paulo: Brasiliense, 1987, pp 205 e 206.

Artigo recebido em 01/2009. Aprovado em 03/2009 